\title{
Margaret McCartney: Can junior doctors feel safe to blow the whistle?
}

\author{
Margaret McCartney GP
}

Glasgow

In April, NHS England published a national whistleblowing policy. "Don't wait for proof," it said. "It doesn't matter if you turn out to be mistaken as long as you are genuinely troubled. . You will not be at risk of losing your job or suffering any form of reprisal as a result."

In 2014 a junior doctor, Chris Day, was covering intensive care when two locum doctors booked to work didn't turn up. Day made a "protected disclosure," a legal process designed to protect whistleblowers, to tell managers that he was dangerously overstretched and that the ward was unsafely staffed.

Day claimed that he was subsequently victimised by the trust and by Health Education England (HEE); the dispute that followed cost him his training number. He ended up losing his training place, with HEE opposing him in court arguing about who was responsible for his employment.

The court found that, because Day was employed by a trust, he had no claim against HEE, which would have been responsible for organising his ongoing appointments. ${ }^{2}$

The court concluded that "this is not a case of a gap within the boundaries of protection, but a case in which the relationship falls well outside those boundaries."

Yet HEE had control of his training number and place of work and contributed to his salary - thus, it controlled his employment.

England's 50 000-odd junior doctors may worry that they lack legal protection from loss of employment if they need to blow the whistle

The Department of Health recently told me, "Junior doctors are fully protected under whistleblowing law. As workers at the trusts who employ them, they are protected by the same whistleblowing law as all other workers." But it's still HEE that controls junior doctors' employment.

Ben Gummer, until recently the health services secretary, confirmed this to me in a statement: "HEE offers training placements to junior doctors and the EAT [Employment Appeal Tribunal] considers this arrangement to be outside the bounds of the protections of whistleblowing law."

So, England's 50 000-odd junior doctors may worry that they lack legal protection from loss of employment if they ever need to blow the whistle. A combative legal process is not the inducement NHS workers need to encourage them to speak up about threats to patients. Until talking about safety is seen and believed to be a safe thing to do, we will continue to fail patients needlessly.

All agencies with control over doctors' employment should be covered by whistleblowing legislation-otherwise the new policy is a waste of ink.

Competing interests: See www.bmj.com/about-bmj/freelancecontributors/margaret-mccartney.

Provenance and peer review: Commissioned; not externally peer reviewed.

Follow Margaret on Twitter, @mgtmccartney

NHS Improvement, NHS England. Freedom to speak up: raising concerns (whistleblowing) policy for the NHS. Apr 2016. https://improvement.nhs.uk/uploads/documents/ whistleblowing_policy_30march.pdf.

2 Employment Cases Update. Day $v$ Lewisham and Greenwich NHS Trust and Health Education England (UKEAT/0250/15/RN). Mar 2016. www.employmentcasesupdate.co. uk/site.aspx?i=ed30735.

Published by the BMJ Publishing Group Limited. For permission to use (where not already granted under a licence) please go to http://group.bmj.com/group/rights-licensing/ permissions 